\title{
Peroxide bleaching agent effects on enamel surface microhardness, roughness and morphology
}

\section{Efeitos de agentes clareadores à base de peróxidos na microdureza, rugosidade e morfologia superficial do esmalte}

\author{
Cristiane Franco Pinto* \\ Rogério de Oliveira** \\ Vanessa Cavalli*** \\ Marcelo Giannini ${ }^{* * * *}$
}

\begin{abstract}
The aim of this study was to evaluate the surface roughness, microhardness and morphology of human enamel exposed to six bleaching agents (at baseline and post-treatment). Human dental enamel samples were obtained from human third molars and randomly divided into seven groups $(\mathrm{n}=11)$ : control, Whiteness Perfect $10 \%$ carbamide peroxide $(10 \% \mathrm{CP})$, Colgate Platinum - $10 \% \mathrm{CP}$, Day White $2 \mathrm{Z}-7.5 \%$ hydrogen peroxide $(7.5 \% \mathrm{HP})$, Whiteness Super - 37\% CP, Opalescence Quick - 35\% CP and Whiteness HP - 35\% HP. Bleaching agents were applied according to manufacturers' instructions. The control group remained not treated and stored in artificial saliva. Microhardness testing was performed with a Knoop indentor and surface roughness was analyzed with a profilometer. Morphologic observations were carried out with scanning electron microscopy (SEM). Results were statistically analyzed by two-way analysis of variance and Tukey's test $(5 \%)$, and revealed a significant decrease in microhardness values and a significant increase in surface roughness post-bleaching. Changes in enamel morphology after bleaching were observed under SEM. It was concluded that bleaching agents can alter the microhardness, roughness and morphology of dental enamel surface.
\end{abstract}

DESCRIPTORS: Tooth bleaching; Peroxides; Dental enamel.

\begin{abstract}
RESUMO: O objetivo deste estudo foi avaliar a rugosidade, microdureza e morfologia superficial do esmalte dental humano tratado com seis agentes clareadores (antes e depois do tratamento). Amostras de esmalte dental humano foram obtidas de terceiros molares e aleatoriamente distribuídas em sete grupos $(\mathrm{n}=11)$ : controle, Whiteness Perfect - peróxido de carbamida a 10\% (PC 10\%), Colgate Platinum - PC 10\%, Day White $2 Z$ - peróxido de hidrogênio a 7,5\% (PH 7,5\%), Whiteness Super - PC 37\%, Opalescence Quick - PC 35\% e Whiteness HP - PH 35\%. Os agentes clareadores foram aplicados de acordo com as instruções dos fabricantes. O grupo controle permaneceu sem tratamento e armazenado em saliva artificial. O teste de microdureza foi realizado com o indentador Knoop, e a rugosidade superficial foi verificada através do rugosímetro. Observações morfológicas foram realizadas através de microscopia eletrônica de varredura (MEV). Os resultados foram estatisticamente analisados com ANOVA (dois fatores) e teste Tukey (5\%) e revelaram uma redução significante nos valores de microdureza e um aumento significante da rugosidade de superfície após o clareamento. Alterações na morfologia do esmalte após o clareamento foram observadas através de MEV. Concluiu-se que os agentes clareadores podem alterar a microdureza, rugosidade e morfologia superficial do esmalte dental.
\end{abstract}

DESCRITORES: Clareamento de dente; Peróxidos; Esmalte dentário.

\section{INTRODUCTION}

Since the introduction of the nightguard vital bleaching technique using $10 \%$ carbamide peroxide $^{9}$, studies have been performed in order to evaluate the adverse effects produced during and after whitening procedures ${ }^{4,5,15,18,21}$. In this conventional bleaching technique, patients wear a customized tray containing the bleaching agent during 5 to 8 hours a day, for 2 to 5 weeks. In an attempt to produce whitening effects similar to those produced by the conventional $10 \%$ carbamide peroxide technique and reduce the whitening treatment period and application time, other bleaching protocols can be used.

Alternative bleaching treatments comprise whitening products with modifications in gel composition or increased peroxide concentrations $s^{7,10,14}$. These bleaching agents include those designed for professional use only containing high concentra-

\footnotetext{
* Master's Degree Student; ***MS, PhD Student; ${ }^{* * * *}$ Associate Professor - Department of Restorative Dentistry, School of Dentistry of Piracicaba, State University of Campinas.

** MS, Private Practice, Brasilia.
} 
Pinto CF, Oliveira R, Cavalli V, Giannini M. Peroxide bleaching agent effects on enamel surface microhardness, roughness and morphology. Braz Oral Res 2004;18(4):306-11.

tions of peroxides (35 to 37\%) and patient-applied tooth whiteners with low carbamide (10 to 20\%) and hydrogen (3 to $7.5 \%$ ) peroxide concentrations $^{16,19}$.

Evidence demonstrates that enamel presents structural changes when exposed to $10 \%$ carbamide peroxide, compromising its composition and morphology ${ }^{1,11,15,18,21}$. However, there is little information about the effects of whitening products that present different peroxide concentrations, formulations and application protocols on enamel surface.

The purpose of this in vitro study was to evaluate the effects of bleaching agents containing high concentration of peroxides for professional use only and materials dispensed and monitored by dentists and used by patients at home on human enamel surface. Knoop microhardness and surface roughness were measured to analyze alterations on bleached enamel surfaces. In addition, enamel surface morphology was observed under scanning electron microscopy (SEM). The hypothesis tested was that different bleaching treatments affect the enamel surface.

\section{MATERIALS AND METHODS Specimen preparation}

Forty extracted sound human third molars, stored in $0.1 \%$ buffered thymol solution (LabSynth, Diadema, SP, Brazil) for no longer than four weeks after extraction were used in this study. The teeth were obtained after informed consent by the patients and under the protocol $(106 / 2001)$ that was analyzed and approved by the Ethical Research Committee, School of Dentistry of Piracicaba, State University of Campinas. The teeth were cleaned of gross debris and placed in deionized water for twenty-four hours before the experiment was initiated.

Roots were removed and approximately 77 enamel fragments were obtained from the crowns with a diamond saw (Isomet 1000, Buehler Ltd., Lake Bluff, IL, USA) under water lubrication. Each dental fragment $(5 \mathrm{~mm} \times 5 \mathrm{~mm} \times 2.5 \mathrm{~mm})$ was embedded in self-curing polystyrene resin cylinders (Piraglass Com. e Ind., Piracicaba, SP, Brazil) (1.5 cm wide by $1.5 \mathrm{~cm}$ high). Enamel surfaces were flattened with wet 600-, 1,000- and 1,200grit aluminum oxide abrasive papers (3M, Sumaré, SP, Brazil) and polished with $6,3,1$ and $1 / 4 \mu \mathrm{m}$-grit diamond pastes (Arotec S.A. Ind. e Com., Cotia, SP, Brazil) on a polishing machine (APL-4, Arotec S.A. Ind. e Com., Cotia, SP, Brazil).

\section{Experimental groups}

Specimens were randomly divided into seven groups ( $\mathrm{n}=11)$, six with different bleaching agents and a control group. Table 1 shows the composition, manufacturer and bleaching regimen of the whitening products used in this study.

The control group was kept in artificial saliva ${ }^{4}$ at $37^{\circ} \mathrm{C}$ for two weeks. For groups treated with Whiteness Perfect (10\% carbamide peroxide $\mathrm{CP})$, Colgate Platinum (10\% CP) and Day White $2 Z$ (7.5\% hydrogen peroxide - HP), enamel surface was daily exposed to a mixture of $0.1 \mathrm{ml}$ of the respective bleaching agent with $0.05 \mathrm{ml}$ of artificial saliva $^{4}$, according to each bleaching regimen. For groups treated with Whiteness Super (37\% CP), Opalescence Quick (35\% CP) and Whiteness HP (35\% HP), only $0.1 \mathrm{ml}$ of bleaching agent was applied to enamel. During the bleaching period, specimens were placed in $100 \%$ relative humidity at

TABLE 1 - Bleaching agent composition, manufacturer and application mode.

\begin{tabular}{l|c|l}
\hline \hline \multicolumn{1}{c|}{ Bleaching agent } & Concentration & \multicolumn{1}{c}{ Regimen } \\
\hline $\begin{array}{l}\text { Whiteness Perfect } \\
\text { (FGM Dental Products, Joinville, SC, Brazil) }\end{array}$ & $10 \% \mathrm{CP}$ & 1 daily application (6 hours) for 14 days \\
\hline $\begin{array}{l}\text { Colgate Platinum } \\
\text { (Colgate Oral Pharmaceutical, Canton, MA, USA) }\end{array}$ & $10 \% \mathrm{CP}$ & 1 daily application (6 hours) for 5 days \\
\hline $\begin{array}{l}\text { Day White 2Z } \\
\text { (Discus Dental Inc., Culver City, CA, USA) }\end{array}$ & $7.5 \% \mathrm{HP}$ & $\begin{array}{l}1 \text { daily application (30 minutes) for 14 } \\
\text { days }\end{array}$ \\
\hline $\begin{array}{l}\text { Whiteness Super } \\
\text { (FGM Dental Products, Joinville, SC, Brazil) }\end{array}$ & $37 \% \mathrm{CP}$ & $\begin{array}{l}\text { 2 applications (30 minutes each) with a } \\
5-\text { day interval }\end{array}$ \\
\hline $\begin{array}{l}\text { Opalescence Quick } \\
\text { (Ultradent Products Inc., Salt Lake City, UT, USA) }\end{array}$ & $35 \% \mathrm{CP}$ & $\begin{array}{l}\text { 2 applications (30 minutes each) with a } \\
5-\text { day interval }\end{array}$ \\
\hline $\begin{array}{l}\text { Whiteness HP } \\
\text { FGM Dental Products, Joinville, SC, Brazil) }\end{array}$ & $35 \% \mathrm{HP}$ & $\begin{array}{l}\text { 2 applications (15 minutes each) with a } \\
\text { 7-day interval }\end{array}$ \\
\hline \hline
\end{tabular}

CP: carbamide peroxide; HP: hydrogen peroxide. 
Pinto CF, Oliveira R, Cavalli V, Giannini M. Peroxide bleaching agent effects on enamel surface microhardness, roughness and morphology. Braz Oral Res 2004;18(4):306-11.

$37^{\circ} \mathrm{C}$. After each bleaching session, specimens were thoroughly rinsed with deionized water for $10 \mathrm{sec}-$ onds and stored in $0.5 \mathrm{ml}$ of artificial saliva at $37^{\circ} \mathrm{C}$ until the next treatment. Following the bleaching regimen, specimens were rinsed and stored in deionized water for $24 \mathrm{~h}$ at $37^{\circ} \mathrm{C}$ before being tested.

\section{Microhardness testing}

Microhardness measurements were taken before initial exposure to the bleaching agents (baseline) and post-treatment. Specimens were positioned perpendicularly to the long axis of the indentor to record the Knoop hardness number (KHN). A 25 g load Knoop indentor ${ }^{3}$ (Future Tech, Tokyo, Japan) attached to a microhardness tester (FM-1e, Future Tech, Tokyo, Japan) performed three measurements during 5 seconds to determine the KHN of each specimen at each time interval in split-plot design. Mean values were statistically analyzed by two-way analysis of variance (ANOVA) and Tukey's test at the $5 \%$ level of significance.

\section{Roughness testing}

A profilometer (Surf-Corder SE 1200, Kosaka Lab Ltd., Tokyo, Japan) was used to measure the surface roughness before (baseline) and after bleaching procedures. Three measurements in different directions were recorded and the average surface roughness $(\mathrm{Ra})$ was determined for each specimen at each time interval in split-plot design. Mean values were statistically analyzed by two-way analysis of variance (ANOVA) and Tukey's test at the $5 \%$ level of significance.

\section{SEM observation}

Dental fragments were removed from the resin cylinders and enamel surfaces were prepared for the scanning electron microscope (VP 435, Leo, Cambridge, England). Enamel surfaces were sputter coated with gold in a vacuum evaporator (MED 010, Balzers, Balzer, Liechtenstein) and photomicrographs of representative areas were taken at 5,000 X magnifications. The enamel changes were classified as no alterations, mild or slight alterations (slight alterations in surface roughness and irregular patterns of conditioning) and altered surfaces (loss of superficial structure).

\section{RESULTS}

Tables 2 and 3 present the KHN and Ra values for each bleaching agent at different time

TABLE 2 - Mean Knoop hardness number ( $\pm \mathrm{SD}$ ) for each treatment at time intervals.

\begin{tabular}{l|c|c}
\hline \multicolumn{1}{c|}{ Treatment } & Baseline & Final \\
\hline Control group & $264.25 \pm 28.17 \mathrm{~A} \mathrm{a}$ & $230.28 \pm 73.03 \mathrm{~A} \mathrm{a}$ \\
\hline Whiteness Perfect - 10\% CP & $283.97 \pm 26.01 \mathrm{~A} \mathrm{a}$ & $61.29 \pm 12.39 \mathrm{~B} \mathrm{~b}$ \\
\hline Colgate Platinum - 10\% CP & $263.64 \pm 35.30 \mathrm{~A} \mathrm{a}$ & $78.11 \pm 21.66 \mathrm{~B} \mathrm{~b}$ \\
\hline Day White 2Z - 7.5\% HP & $294.09 \pm 43.05 \mathrm{~A} \mathrm{a}$ & $61.42 \pm 11.19 \mathrm{~B} \mathrm{~b}$ \\
\hline Whiteness Super - 37\% CP & $264.79 \pm 39.99 \mathrm{~A} \mathrm{a}$ & $51.02 \pm 16.38 \mathrm{~B} \mathrm{~b}$ \\
\hline Opalescence Quick - 35\% CP & $290.62 \pm 35.97 \mathrm{~A} \mathrm{a}$ & $44.42 \pm 11.80 \mathrm{~B} \mathrm{~b}$ \\
\hline Whiteness HP - 35\% HP & $255.72 \pm 31.78 \mathrm{~A} \mathrm{a}$ & $\mathrm{B}$ \\
\hline \hline
\end{tabular}

Means followed by different letters (capital letter - column and lower case - line) differ by Tukey's test (p < 0.05). CP: carbamide peroxide, HP: hydrogen peroxide, SD: standard deviation.

TABLE 3 - Mean values $( \pm \mathrm{SD})$ of surface roughness $(\mathrm{Ra})$ in $\mu \mathrm{m}$ for each treatment at time intervals.

\begin{tabular}{l|c|c}
\hline \multicolumn{1}{c|}{ Treatment } & Baseline & Final \\
\hline Control group & $0.17 \pm 0.06 \mathrm{~A} \mathrm{a}$ & $0.23 \pm 0.04 \mathrm{~A} \mathrm{a}$ \\
\hline Whiteness Perfect - 10\% CP & $0.20 \pm 0.05 \mathrm{~A} \mathrm{a}$ & $0.27 \pm 0.05 \mathrm{AB} \mathrm{b}$ \\
\hline Colgate Platinum - 10\% CP & $0.21 \pm 0.07 \mathrm{~A} \mathrm{a}$ & $0.32 \pm 0.11 \mathrm{AB} \mathrm{b}$ \\
\hline Day White 2Z - 7.5\% HP & $0.19 \pm 0.06 \mathrm{~A} \mathrm{a}$ & $0.32 \pm 0.10 \mathrm{AB} \mathrm{b}$ \\
\hline Whiteness Super - 37\% CP & $0.20 \pm 0.06 \mathrm{~A} \mathrm{a}$ & $0.33 \pm 0.07 \mathrm{AB} \mathrm{b}$ \\
\hline Opalescence Quick - 35\% CP & $0.15 \pm 0.05 \mathrm{~A} \mathrm{a}$ & $0.27 \pm 0.07 \mathrm{AB} \mathrm{b}$ \\
\hline Whiteness HP - 35\% HP & $0.16 \pm 0.04 \mathrm{~A} \mathrm{a}$ & $0.35 \pm 0.06 \mathrm{~B} \mathrm{~b}$ \\
\hline \hline
\end{tabular}

Means followed by different letters (capital letter - column and lower case - line) differ by Tukey's test $(p<0.05)$. CP: carbamide peroxide, HP: hydrogen peroxide, SD: standard deviation. 
Pinto CF, Oliveira R, Cavalli V, Giannini M. Peroxide bleaching agent effects on enamel surface microhardness, roughness and morphology. Braz Oral Res 2004;18(4):306-11.

intervals, respectively. For both tests, the mean values followed normal distribution and ANOVA detected statistically significant differences among groups $(\mathrm{p}<0.001$ and $\mathrm{p}=0.0103$, respectively) and between time intervals $(p<0.001)$. The interactions between factors (bleaching agents and time intervals) were also significant ( $p<0.001$ and $\mathrm{p}=0.0372$, respectively).

Tukey's test showed that initial KHN was similar for all groups $(p>0.05)$. However, specimens submitted to all bleaching regimens presented reduction in KHN ( $<$ 0.05). Moreover, all groups presented similar initial Ra values $(p>0.05)$. After bleaching treatments, enamel presented increased surface roughness $(p<0.05)$. However, only high-concentrated hydrogen peroxide $(35 \%)$

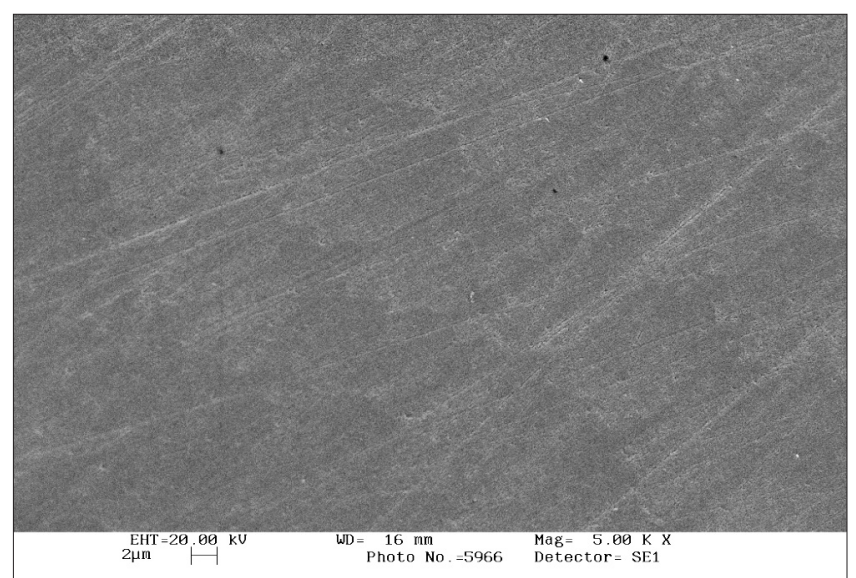

FIGURE 1 - Enamel surface morphology of unbleached control group. A smooth and unchanged surface is noted $(5,000 \mathrm{X})$.

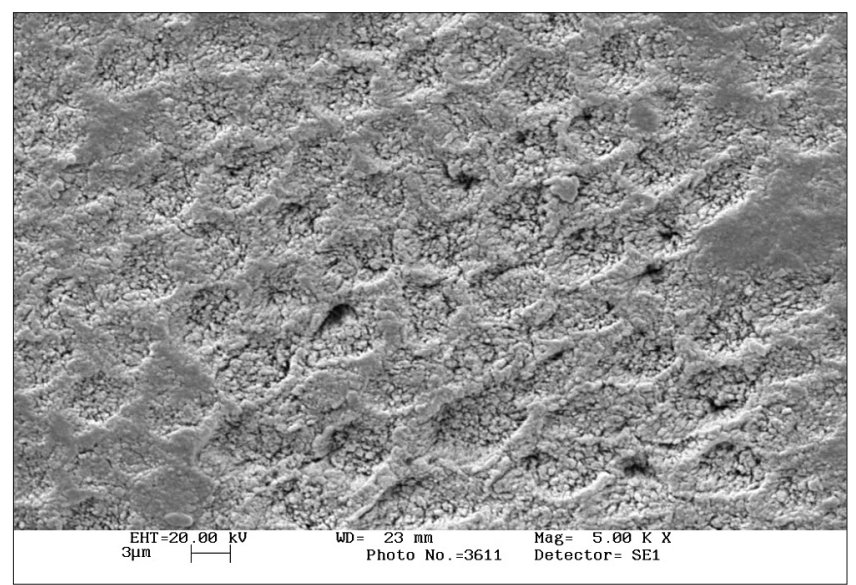

FIGURE 2 - Enamel surface exposed to Whiteness Perfect ( $10 \%$ carbamide peroxide). Mild intraprismatic dissolution was produced on the surface $(5,000 \mathrm{X})$. produced Ra values significantly higher than those of the control group, which was kept in artificial saliva $(\mathrm{p}<0.05)$.

A representative photomicrograph of polished enamel surface stored 14 days in artificial saliva (control group) is shown in Figure 1. No significant morphologic alterations were detected on unbleached enamel surfaces. Bleached groups showed alterations on surface smoothness and presented different levels of surface changes (Figures 2 to 7). While Whiteness Super bleaching agent regimen ( $37 \%$ carbamide peroxide) induced minor alterations on enamel surface (Figure 5), hydrogen peroxide used in high concentration (Whiteness HP - 35\%) promoted dissolution of some enamel superficial areas (Figure 7).

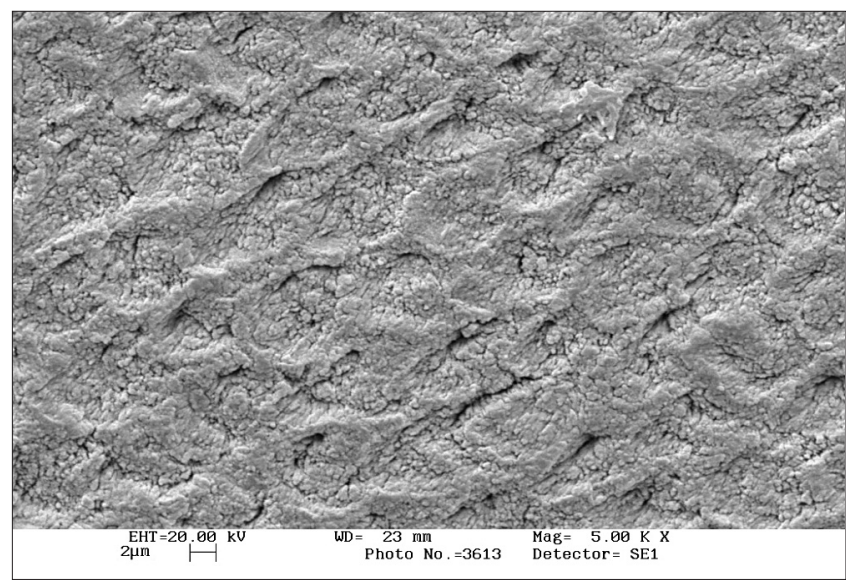

FIGURE 3 - Enamel surface exposed to Colgate Platinum $(10 \%$ carbamide peroxide). Mild intraprismatic dissolution was produced on the surface $(5,000 \mathrm{X})$.

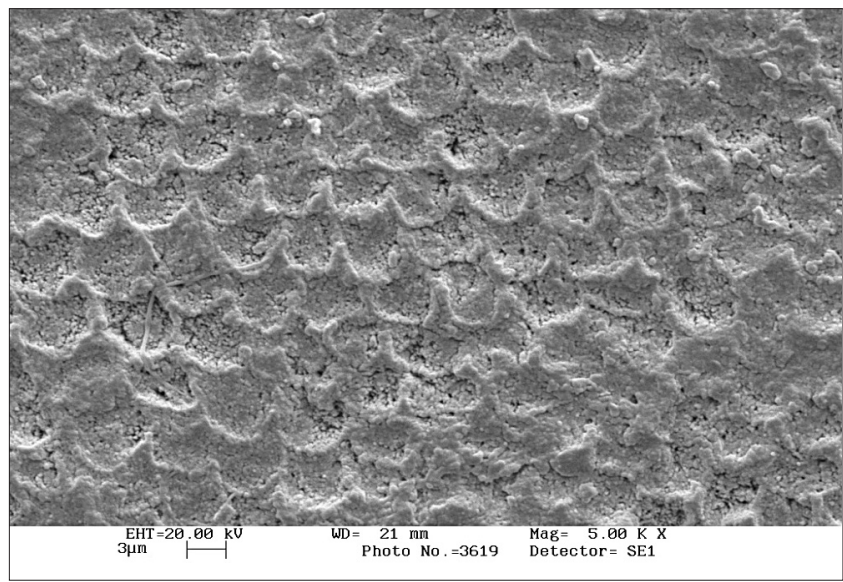

FIGURE 4 - Enamel surface exposed to Day White $2 Z$ (7.5\% hydrogen peroxide). Mild intraprismatic dissolution was produced on the surface $(5,000 \mathrm{X})$. 
Pinto CF, Oliveira R, Cavalli V, Giannini M. Peroxide bleaching agent effects on enamel surface microhardness, roughness and morphology. Braz Oral Res 2004;18(4):306-11.

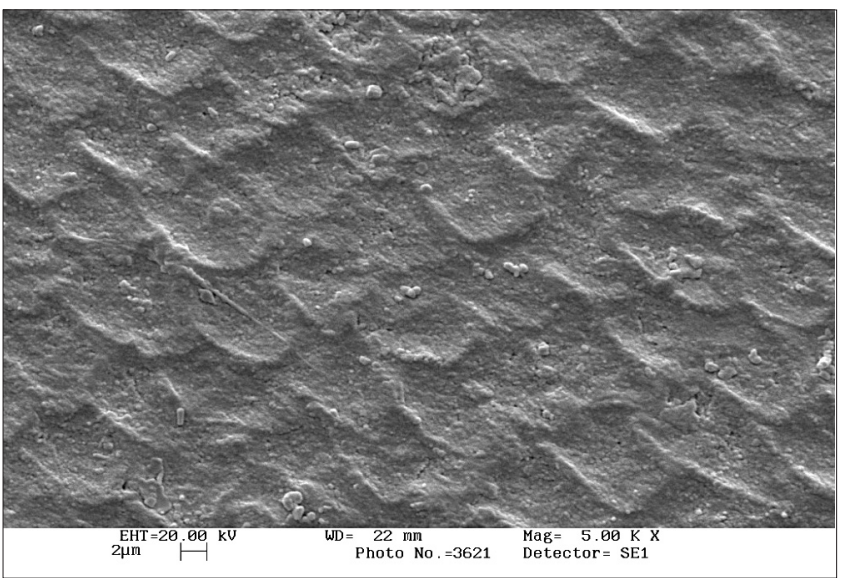

FIGURE 5 - Enamel surface exposed to Whiteness Super $(37 \%$ carbamide peroxide). Mildly changed areas and the interprismatic limits are noted $(5,000 \mathrm{X})$.

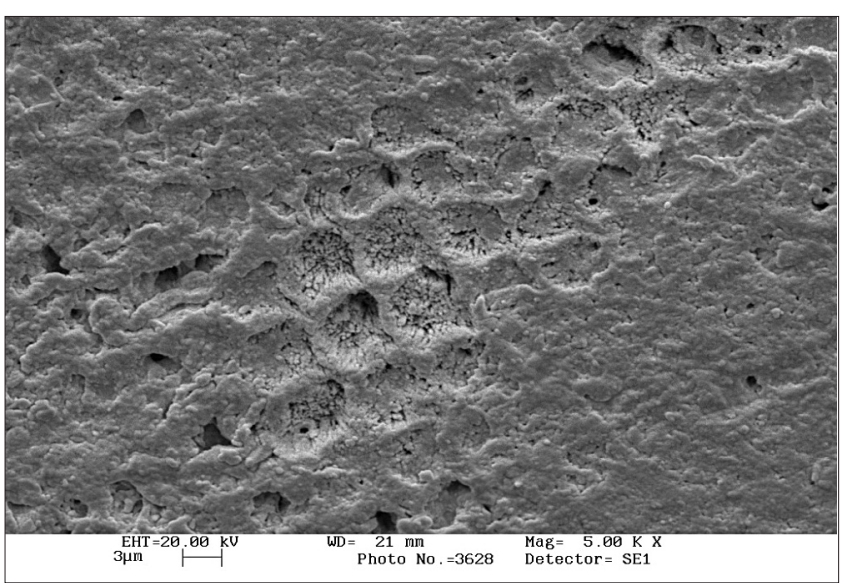

FIGURE 6 - Enamel surface exposed to Opalescence Quick (35\% carbamide peroxide). Mild intraprismatic dissolution was produced on the surface $(5,000 \mathrm{X})$.

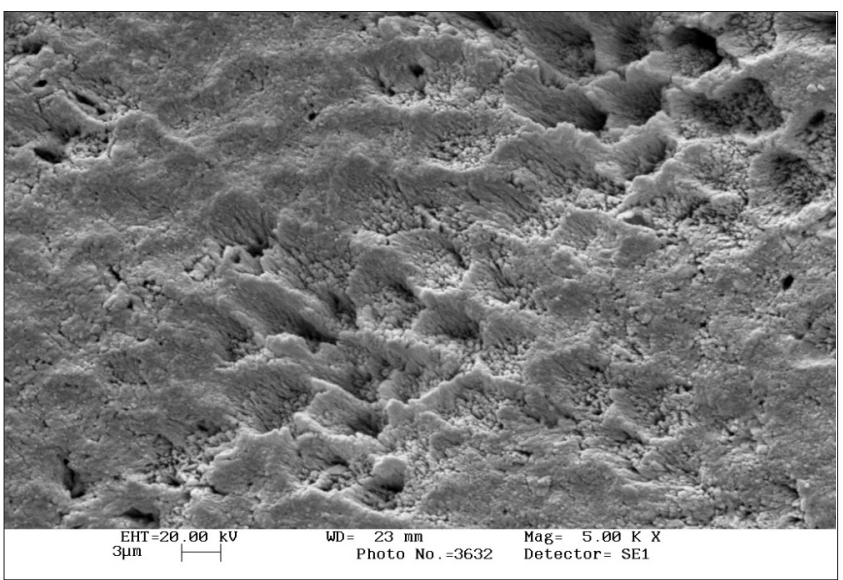

FIGURE 7 - Enamel surface exposed to Whiteness HP (35\% hydrogen peroxide). Erosion or intraprismatic structure dissolution can be noted $(5,000 \mathrm{X})$.

\section{DISCUSSION}

In this study, after all bleaching regimens, enamel surface presented reduction in Knoop microhardness and increase in surface roughness. While alterations on enamel surface produced by bleaching oxidizing process roughened the surface, the loss of mineral content and organic matrix decreased enamel microhardness. Previous studies have shown changes in enamel components and morphology $1,6,11,18$, microhardness ${ }^{1,6}$ and fracture toughness ${ }^{4,21}$ reduction after bleaching with $10 \%$ carbamide peroxide.

Specimens from the control group, stored in artificial saliva for 2 weeks, showed no changes in Knoop microhardness, surface roughness or morphology. Therefore, artificial saliva had no effect on enamel surface (Figure 1). Conversely, regardless of the whitening product used, bleaching agents showed similar performance in both enamel superficial analysis, although the products present different bleaching regimen, composition and peroxide concentration. SEM evaluation revealed surface alterations on enamel after all bleaching procedures. Micrographs of the bleached enamel surfaces showed pits, waviness, erosions and surface roughness (Figures 2 to 7 ).

The group using hydrogen peroxide in high concentration (Whiteness HP - 35\%) was the only one presenting Ra values significantly higher than those of the control group. Previous studies have indicated that $30-35 \%$ hydrogen peroxide causes superficial alterations and reduction in the calcium-phosphorus ratio ${ }^{13,15,20,22}$. Because 35\% hydrogen peroxide is a strong oxidizing agent, it is indicated for professional use only at the dental office. In this study, after 35\% hydrogen peroxide treatment, some areas of enamel surface presented no alterations. However, in other areas, demineralization and lack of smoothness probably resulted in an increase of average surface roughness (Figure 7).

High concentration of carbamide peroxide $(35-37 \%)$ is indicated as pre-treatment and in association with at-home vital bleaching. These products are for professional use only, even though approximately $11 \%$ of hydrogen peroxide is produced after the peroxide degradation. Minor superficial alterations were noted for $37 \%$ carbamide peroxide Whiteness Super bleaching agent under SEM (Figure 5). The alterations produced by high concentrations of carbamide peroxide (Figure 6) were similar to those produced by whitening products indicated for at-home use (Figures 2 to 4). Use of a custom-fitted tray as a carrier for low concentrations of carbamide $(10 \%)$ and hydrogen 
Pinto CF, Oliveira R, Cavalli V, Giannini M. Peroxide bleaching agent effects on enamel surface microhardness, roughness and morphology. Braz Oral Res 2004;18(4):306-11.

peroxide $(7.5 \%)$ for prolonged periods (2-5 weeks) during the day or at night is conventional bleaching technique recommended by dentists. According to clinical experiences and researches, daily exposure to $10 \%$ carbamide peroxide is an apparently safe and effective procedure for whitening tooth hard tissues ${ }^{9,10,16}$.

As a result of bleaching regimens, the reduction in Knoop microhardness due to mineral loss can be naturally controlled by saliva and with remineralizing solution, such as artificial saliva and fluorides ${ }^{1,4,8,18}$. In vitro studies seem to yield more pronounced effects than in vivo conditions ${ }^{12}$. However, no remineralizing effect can recover the enamel initial surface roughness promoted by polishing with diamond pastes during specimen preparation. Clinically, to recover enamel smoothness and restore its lustrous surface altered by the application of high-concentrated hydrogen peroxide gels, polishing enamel after bleaching sessions is required ${ }^{2,9,17}$. However, polishing procedures can result in enamel loss of some micrometers, reduc-

\section{REFERENCES}

1. Akal N, Over H, Olmez A, Bodur H. Effects of carbamide peroxide containing bleaching agents on the morphology and subsurface hardness of enamel. J Clin Pediatr Dent 2001;25:293-6.

2. Arens D. The role of bleaching in esthetics. Dent Clin North Am 1989;33:319-36.

3. Argenta RM, Tabchoury CP, Cury JA. A modified pH-cycling model to evaluate fluoride effect on enamel demineralization. Pesqui Odontol Bras 2003;17:241-6.

4. Cavalli V, Giannini M, Carvalho RM. Effect of carbamide peroxide bleaching agents on tensile strength of human enamel. Dent Mater 2004;8:733-9.

5. Cavalli V, Reis AF, Giannini M, Ambrosano GMB. The effect of elapsed time following bleaching on enamel bond strength of resin composite. Oper Dent 2001;26:597-602.

6. Cimilli $\mathrm{H}$, Pameijer $\mathrm{CH}$. Effect of carbamide peroxide bleaching agents on the physical properties and chemical composition of enamel. Am J Dent 2001;14:63-6.

7. Clark DM, Hintz J. Case report: in-office tooth whitening procedure with $35 \%$ carbamide peroxide evaluated by the Minolta CR-321 Chroma Meter. J Esthet Dent 1998;10:3742 .

8. Flaitz CM, Hicks MJ. Effects of carbamide peroxide whitening agents on enamel surfaces and caries-like lesion formation: an SEM and polarized light microscopic in vitro study. ASDC J Dent Child 1996;63:249-56.

9. Haywood VB, Heymann HO. Nightguard vital bleaching. Quintessence Int 1989;20:173-6.

10. Haywood VB, Robinson RG. Vital tooth bleaching with nightguard vital bleaching. Curr Opin Cosmet Dent 1997;4:45-52

11. Hegedüs C, Bistey T, Flóra-Nagy E, Keszthelyi G, Jenei A. An atomic force microscopy study on the effect of bleaching agents on enamel surface. J Dent 1999;27:509-15.

12. Justino LM, Tames DR, Demarco FF. In situ and in vitro effects of bleaching with carbamide peroxide on human enamel. Oper Dent 2004;29:219-25. ing enamel thickness and removal of the superficial layer.

\section{CONCLUSIONS}

1. After bleaching procedures, all bleaching agents promoted a reduction in enamel microhardness and an increase in surface roughness.

2. Compared to unbleached specimens stored in artificial saliva, the exposure to $35 \%$ hydrogen peroxide increased roughness and significantly altered enamel superficial morphology.

\section{ACKNOWLEDGMENTS}

The authors are indebted to Dr. E. W. Kitajima, Nucleus of Research Support, Electron Microscopy Center (NAP/MEPA-ESALQ-USP) for electron microscopy support. This study was supported by grants 01/13034-3 and 01/02771-7 (FAPESP), and by PIBIC/CNPq-PRP/UNICAMP.

13. Lee CQ, Cobb CM, Zargartalebi F, Hu N. Effect of bleaching on microhardness, morphology, and color of enamel. Gen Dent 1995;43:158-62.

14. Lyons $\mathrm{K}, \mathrm{Ng} \mathrm{B}$. Nightguard vital bleaching: a review and clinical study. N Z Dent J 1998;94:100-5.

15. McGuckin RS, Babin JF, Meyer BJ. Alterations in human enamel surface morphology following vital bleaching. J Prosthet Dent 1992;68:754-60.

16. Mokhlis GR, Matis BA, Cochran MA, Eckert GJ. A clinical evaluation of carbamide peroxide and hydrogen peroxide whitening agents during daytime use. J Am Dent Assoc 2000;131:1269-77.

17. Nathanson D, Parra C. Bleaching vital teeth: a review and clinical study. Compendium 1987;8:490-2,494,4967.

18. Perdigão J, Francci C, Swift EJ Jr, Ambrose WW, Lopes M. Ultra-morphological study of the interaction of dental adhesives with carbamide peroxide-bleached enamel. Am J Dent 1998;11:291-301.

19. Price RBT, Sedarous M, Hiltz GS. The $\mathrm{pH}$ of toothwhitening products. J Can Dent Assoc 2000;66:421-6.

20. Rotstein I, Dankner E, Goldman A, Heling I, Stabholz A, Zalkind M. Histochemical analysis of dental hard tissues following bleaching. J Endod 1996;22:23-6.

21. Seghi RR, Denry I. Effects of external bleaching on indentation and abrasion characteristics of human enamel in vitro. J Dent Res 1992;71:1340-4.

22. Titley K, Torneck CD, Smith D. The effect of concentrated hydrogen peroxide solutions on the surface morphology of human tooth enamel. J Endod 1988;14:69-74.

Received for publication on May 18, 2004

Sent for alterations on Sep 29, 2004

Accepted for publication on Nov 23, 2004 